\title{
Derrida and the Problem of History 1964-1965
}

\author{
Sean Gaston
}

HISTORICITY AND NON-HISTORICITY

One can only praise the patience and care of Thomas Dutoit, Marguerite Derrida and Geoffrey Bennington for deciphering the hand-written lectures that Jacques Derrida delivered at the Ecole Normale Supérieure in late 1964 and early $1965{ }^{1}$ The publication of Heidegger: The Question of Being and History gives us an extended examination of the problem of history prior to Of Grammatology (1967). Despite its opening dismissal of “the classical categories of history,” Derrida would later insist that Of Grammatology was “a history book through and through.” 2 Derrida’s most celebrated work argues that neither speech nor nature can be taken as an a-historical essence because to register itself as natural it must be supplemented by the cultural, the conventional and the historical. At the same time, this supplement cannot be taken as a historical determination. Derrida’s "history book” evokes fluid terms such as the trace and differance to account for a new history of metaphysical concepts that cannot be reduced to a customary historicism. 
In his subsequent work, which responded in part to the common charge of an ahistorical underpinning, Derrida took pains to emphasize that whatever has been historically instituted, founded or constructed can be deconstructed because "neither their origin nor their solidity is natural.” ${ }^{3}$ Once the dust settles over Derrida's use of the term text to describe a differentiated framework that exceeds both the claims of linguistics for a pure science of language and the metaphysical motifs that still dominate the treatment of speech and writing in philosophy, we may come to see that history was the great problem that dominated Derrida's philosophical thinking in the 1950s and 1960s. As Edward Baring justly observes, “deconstruction would not have appeared quite so threatening [to historians] if it did not in some way address central problems of historical understanding." 4

Before the Heidegger lectures, Derrida’s earliest work had already shown a critical preoccupation with the uneasy relation between philosophy and history, especially with Edmund Husserl's treatment of the differing demands of the structural and the genetic (or the developmental) and the necessary transcendence in phenomenology of empirical, relativistic historicism. ${ }^{5}$ The 1964-1965 lectures are significant because they provide an insight into Derrida’s detailed response to Martin Heidegger's treatment of history in Being and Time (1927) as he began to formulate his critique of speech and writing.

Derrida's recollections of the contexts for the 1964-1965 lectures suggest that history was as much a political as a philosophical problem in this period. Derrida had been invited by Louis Althusser to return to the Ecole Normale Supérieure in 1964 at the very moment when Althusser was beginning his influential seminar on Marx that would give rise to Reading Capital (1965). In his seminar Althusser explored the relation between Marxism and structuralism and argued that Marxism could be should 
not be reduced to an empirical historicism. ${ }^{6}$ As Derrida recalled in a 1989 interview with Michael Sprinker, he was not persuaded by Althusser's treatment of history. "Many questions seemed to me to have been passed over," he remarks, "notably those about the historicity of history or the concept of history.” 7 These questions had been prompted by Derrida’s earlier analysis of “the conditions of possibility for a history of ideal objectivity” in Husserlian phenomenology ( $\underline{\mathrm{PF}}$ 151). The phenomenological problem of charting the historical development of a necessarily a-historical objectivity in science and language had led Derrida in the early 1960s to a more "preliminary” question about “history’s historicity” (F 152).

Starting his first seminar at the ENS on history raised a political difficulty for Derrida in part because though he was not a member of the French Communist Party, he did not want his work to be "taken for crude and self serving criticisms connected with the right or left” (PF 152). As is more widely appreciated today, Derrida's relation to politics, and specifically to Marxism, was always shaped by the febrile atmosphere of Paris. ${ }^{8}$ In the 1964-1965 lectures, Derrida is clear in his critique of Marxism: it has so far failed to radicalize the thought of historicity ( $\underline{\mathrm{H}}$ 53). Derrida's other difficulty was his choice of devoting his entire seminar to Heidegger. As Dominique Janicaud notes, while there were occasional sharp debates about Heidegger's politics in France from the 1940s, it was only in the 1980s that these led to persistent and widespread discussion. ${ }^{9}$ Derrida would remark in 1968 that his own reading of Heidegger was intent on avoiding the common extremes in France of reverent discipleship or outright condemnation. ${ }^{10}$ As we shall see, on two occasions Derrida addresses Heidegger's association with National Socialism in the 1964-1965 lectures. 
There is a fifty-year gap between Derrida’s 1964 lectures and the publication of Heidegger’s Black Notebooks in 2014. Heidegger’s Ponderings (Überlegungen) comprise his private diaries kept in a series of small black notebooks, notably from 1931-1941. ${ }^{11}$ Derrida of course did not have access to this material. However, as Jean-Luc Nancy suggests in his convincing analysis of the Black Notebooks, there is an aspect of Heidegger's notebooks that relates directly to Derrida's treatment of historicity (宛chichtlichkeit) in Being and Time. As Nancy points out, in his diaries from the late 1930s Heidegger unequivocally links “the deconstruction (․ㅡbau)" of metaphysical ontology to "the destruction (Zerstörung)" of those who appear "to destroy the world and history.” 12 As Nancy argues, for Heidegger there must be a destruction of the absence of historicity (Geschichtslosigkeit) and this absence is emphatically associated with the Jewish people, a people who are described as “without soil, without history." 13

Given the relentless uncovering in the last thirty years of Heidegger's relation to National Socialism and anti-Semitism or anti-Judaism, the more we learn about Heidegger the more we see that Emmanuel Levinas was right. ${ }^{14}$ As Levinas observed in 1963 at a conference organised by Vladimir Jankélévitch on Jewish consciousness, history and forgiveness, “One can forgive many Germans, but there are some Germans it is difficult to forgive. It is difficult to forgive Heidegger.” ${ }^{15}$ As Derrida himself remarked in 1988 at a conference in Heidelberg on Heidegger and politics, in the wake of Heidegger's "terrible silence" on the Shoah, there is "the necessity of reading Heidegger as he did not read himself.” 16

As Nancy aptly observes, the immense influence of Heidegger on twentiethcentury philosophy rests on his emphatic dismissal of the self as the central axis of the philosophical project. His displacement of the classical substantive (ousia) in Being 
and Time opens a new relation to the event (of what is to come, to happen) and to the subject as that which is sent off or sent out (from, with and towards the other). ${ }^{17}$ After his first substantial essay on Heidegger, “Ousia and Grammē” (1968), Derrida’s extended critique of Heidegger would focus on the radical possibilities of the subject

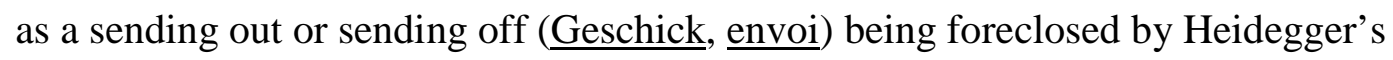
persistent emphasis on a destiny with a destination. ${ }^{18}$ In a series of publications from the early 1980s until his death in 2004, Derrida explored a range of sexual, racial, political, anthropological and historical determinations in Heidegger's thought that limited, undermined and darkened the bright promises of Being and Time. ${ }^{19}$

What makes Derrida’s 1964-1965 lectures dramatically different from a reading of Heidegger after the publication of the Black Notebooks is the possibility of an ethics and politics based on Heidegger's treatment of historicity and non-historicity in Being and Time. Derrida devotes the end of his fourth lecture to emphasising a critical difference between Hegel and Heidegger: in Being and Time the authentic and inauthentic are both “modes of Geschichtlichkeit” ( $\underline{\mathrm{H}}$ 98). ${ }^{20}$ The absence of historical consciousness, Derrida argues, should therefore be understood “as a deficient mode of historicity rather than a mode of non-historicity” (브 99). It is

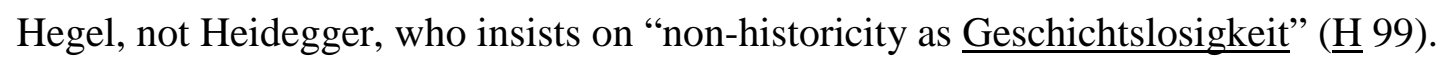
It is Hegel, not Heidegger, who argues "a people that does not have the politics of its historical science - such a people has no history, is not geschichtlich” (프 102). This

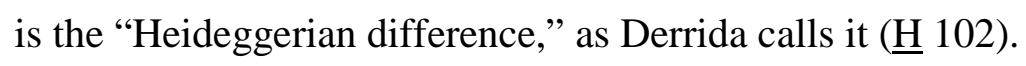

As Derrida points out, like Hegel, Husserl used his definition of historicity to

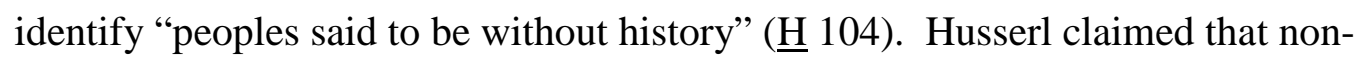
European cultures only demonstrate an “empirical historicity,” which can be taken "as

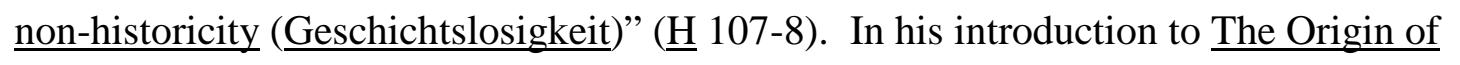


Geometry (1962), Derrida had asked how it was possible for Husserl to "reconcile the affirmation according to which historicity is an essential structure of the horizon for all humanity, as well as for every community, and the allusion to the 'non-historicity' (Geschichtslosigkeit) of certain archaic societies?” ${ }^{21}$ In contrast, as Derrida observes in the 1964-1965 lectures, the refusal to construct a notion of historicity that requires the declaration and imposition of non-historicity shows how Heidegger "breaks with this Hegelian-Husserlian metaphysics of history, this spiritualist metaphysics, this metaphysics of Geist” (ㅍ 104).

As we now know, Derrida came to see that the "Heideggerian difference" was, after all, not that different - starting with the evocation of spirit (Geist) itself. ${ }^{22}$ Derrida’s later work shows a wider interest in the idiomatic difference between Geschichtlichkeit and Geschichtslosigkeit. In a 1983 article he suggests that even if Heidegger does not proclaim a "sexlessness (Geschlechtslosigkeit)" in Being and Time, the attempt to secure non-differentiated, neutralised concepts and to assert the possibility of controlled or directed negations is still to be found in Heidegger's thought in this period. ${ }^{23}$ Derrida had already noted in Glas (1974) Hegel's insistence that the brother-sister relation is uniquely “a-sexual (geschlechtloses)” as part of series of concepts that Hegel evokes to safeguard pure or absolute differences against the perpetual and progressive differentiations of the Aufhebung in the history of spirit. ${ }^{24}$ Indeed, Derrida's interest in the proximity of Heidegger and Hegel is one of the most striking features of the 1964-1965 lectures.

It is to be expected that the question of history would require some reflections on Hegel and his influential use of history in the service of philosophy. Derrida will write in Of Grammatology that the Hegelian Aufhebung - a negating, conserving and progressively uplifting movement - is "the concept of history and of teleology” ( $\underline{G}$ 
25). ${ }^{25}$ Nonetheless, the privileged place of Hegel in a series of lectures on Being and Time is remarkable. At the outset Derrida contrasts Heidegger's destruction of the history of ontology with Hegel's insistence that historicity only begins with the end of

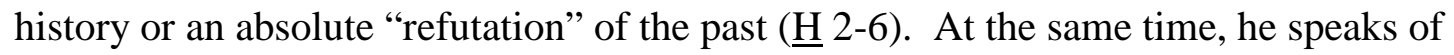
“troubling resemblances” between Heidegger and Hegel (프 9).

In the first lecture Derrida argues, not entirely persuasively, that Heidegger avoids the Hegelian trap of declaring himself the last philosopher in the history of philosophy by "adding no other proposition" once the destruction of the history of ontology has taken place ( $\underline{\mathrm{H}}$ 9). In contrast, in the second lecture Derrida questions Heidegger's emphatic rejection at the start of Being and Time of "telling stories" (aconter des $\underline{\text { histoires }})$ and describes Hegel as one of the "greatest novelists of philosophy” (프 26, 39; $\underline{\text { BT } 6) . ~}{ }^{26}$ Though Derrida goes on to explain Heidegger's critique of les romans de Descartes (the assumption of a self-conscious subject and its narratives as the locus of philosophy), there is already a more equivocal account of Hegel (프 39). ${ }^{27}$

The fourth lecture, as we have seen, draws a clear distinction between a historicity that does not require an attendant designation of non-historicity (Heidegger) and one that clearly does (Hegel). Yet even here Derrida’s language shows that he is always conscious of the proximity of Heidegger and Hegel ( $\underline{H}$ 99, 174-75). This is partly methodological, as he will not want to claim an absolute difference between the philosophers in the name of a more nuanced concept of difference. However, this resemblance is apparent even when Derrida reiterates that they can never be confused, since Heidegger removes consciousness, self-consciousness and experience from its central place in the philosophical tradition (프 100-2).

Though Derrida will again insist in the sixth lecture that the absence of any experience of consciousness in Being and Time marks a "decisive” difference 
between the two philosophers, we are left with a pervasive intimation of Hegelian gestures in "the proper field of an analytic of the historicity of Dasein" (프 150). The constant return to Heidegger’s “dialogue with Hegel” allows Derrida to start to think of the unequivocal in Heidegger ( $\underline{\mathrm{H}} 206)$. From the 1980s to his final seminar, this proximity will become more apparent as Derrida focused on Heidegger's argument in his 1929-1930 seminar that while the stone has no world (weltlos) and the animal is deprived of the world (weltarm), man undertakes a world forming (weltbildend) domination (Walten). ${ }^{28}$

While Derrida reinforces the Heideggerian difference when it comes to the Hegelian opposition of historicity and non-historicity, he is acutely aware of Heidegger's politics. ${ }^{29}$ In the eighth lecture, he observes that when Heidegger links

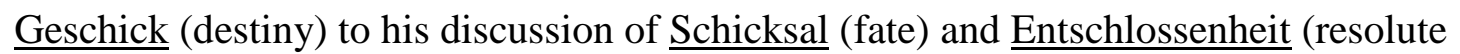
decision) in $\S 74$ of Being and Time, he also expands the discussion of being-with

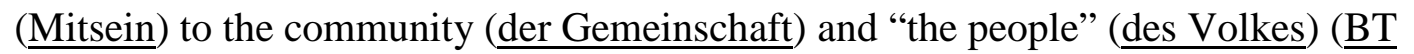
384). As Derrida explains, “And so the historical destiny, historicity, is essentially and originally communitarian. And it is against the structural background of this originary community and this originary historicity that a history can be determined ontically, as by struggle, recognition, and so forth. Entschlossenheit: not heroic individuals but communitarian resolution (support of Nazism [cohésion au nazisme])” (ㅂ 288). ${ }^{30}$ This can be seen as an early articulation of Derrida's critical treatment of a politics based on community. ${ }^{31}$

The other reference to National Socialism is more complex because it is part of Derrida's wider examination of the relation between language, history and the onticoontological difference in Heidegger's thought. It is prompted by Heidegger's insistence in "The Letter on 'Humanism' ” (1946) that "language itself” registers the 
essential “nearness” and “house” of Being. ${ }^{32}$ Derrida suggests that Heidegger’s later work has more obvious political problems, which can be seen in their style and tone. In this case, "there appears what yet again resembles a pure and simple metaphor in

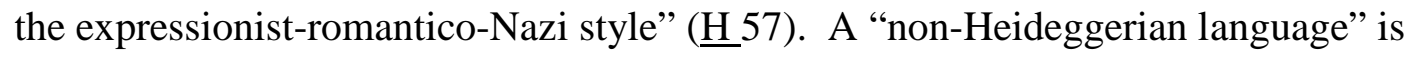

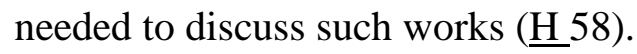

However, Derrida follows his critique of this passage in "The Letter on 'Humanism' ” with a long parenthetical comment: “there appears what yet again resembles a pure and simple metaphor in the expressionist-romantico-Nazi style (which is perhaps - without a doubt even - also romantic-Nazi, but the problem, our problem, is that of knowing if it is only a metaphor and if its romantic-Nazi style exhausts it: and if, allowing oneself to be fascinated by this style, one is not missing, through another philological violence, the essential point)” (ㅍ 57). What is the “essential point”? It is likely that Heidegger’s critique of thinking language through the essence of man - humanism - itself reflects a "romantico-Nazi” thinking. This political analysis is then complicated because of the question of metaphor. ${ }^{33}$

Derrida had been interested in the problem of metaphor in Heidegger's thought in “Violence and Metaphysics,” his long 1964 essay on Levinas. For Heidegger, he observed, "Being is nothing outside the existent” and it is therefore "impossible to avoid the ontic metaphor in order to articulate Being in language.” ${ }^{34}$ In the second and third lectures, Derrida explores the possibilities and the limits of the ontic metaphor. Heidegger can be said to encourage a new critical level of thinking about metaphors and the best example of this is the analysis in Being and Time of the near and far. What is "near" for Being is "far" for being (BT 16). This should allow Heidegger to disrupt the powerful metaphysical metaphor of proximity and its support for self-identity and the "I am" as the self-evident affirmation of the presence of the 
present ( $\underline{\mathrm{H}}$ 52-4). The method suggested by the ontico-ontological difference enables us to highlight and “destroy” these persistent metaphors in the philosophical tradition (ㅂ 53-4). This gives a context for Derrida’s problem when it comes to Heidegger's insistence in 1946 that language simply registers the proximity of Being. ${ }^{35}$

At the same time, Derrida reinforces the extraordinary challenge raised by Heidegger's insight into the relation between metaphor, language and history. In "Violence and Metaphysics," he had wagered that "if there is no history, except through language and if language (except when it names Being itself or nothing: almost nothing) is elementally metaphorical” one can then understand Borges when he suggests, "it may be that universal history is the history of the different intonations given a handful of metaphors” (VM 92). ${ }^{36}$ Derrida returns to Borges in his eighth lecture and offers a striking elaboration. There is a "discourse of thought” that grasps “one will only ever destroy metaphors with the help of other metaphors” (브 189). This is what Derrida himself undertakes in his critique of Levinas: a rubbing together and wearing out of metaphors at work in philosophy such as finite and infinite, internal and external, same and other, etc. (VM 112-13).

Importantly, Derrida also suggests in the lectures that there can be a different manner of dealing with metaphor from merely "substituting one metaphor for another

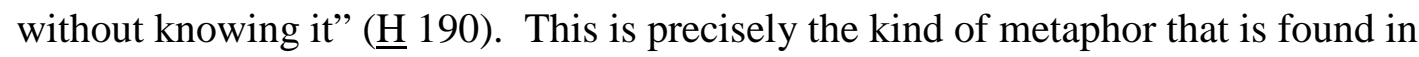
the universal history that Borges identifies ( $\underline{\mathrm{H}}$ 190). One can contrast this perpetual history of metaphors to a thinking that knows "what it is doing" when it comes to destroying metaphor ( $\underline{\mathrm{H}}$ 190). The key difference is the level of awareness that one has when dealing with metaphor as a problem of language and history. For Derrida, Heidegger prompts a "thinking metaphor in metaphorizing it as such, thinking the essence of metaphor” ( $\underline{H}$ 190). Derrida implies in the last pages of his lectures that 
this heightened awareness of metaphor also leads to the wider question of thinking Being and historicity as described in Being and Time as still inherently metaphorical

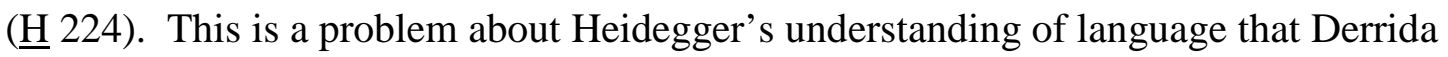
will address in Of Grammatology ( $\underline{G} 18-26)$.

In his discussion of Heidegger’s “romantico-Nazi style” Derrida registers both the magnitude of Heidegger's philosophical insight into metaphor and his profound political failures. Derrida's approach to Heidegger here can be compared to that of his 1965 essay on Antonin Artaud, “La parole soufflée.” Reading Artaud “at the limit," Derrida charts both Artaud's adherence to the metaphysical tradition and the points where he exceeds this tradition. ${ }^{37}$ Significantly, Derrida relates this style of reading to an interpretation of Heidegger and the problem of history. Heidegger's destruction of the history of ontology should not be taken as a "simple surpassing of this history" (도 194). The challenge is recognise a "historicity” that is "neither within nor outside this history” (모 193, 194). ${ }^{38}$

\section{DIFFERENCE, REPETITION AND HISTORICITY}

In Being and Time Heidegger attempts to establish a new understanding of history that is no longer tied to the metaphysical subject (or the primacy of presence) and which lends itself to a science of history only by first recognising its possibility in the existential analytic of Dasein (BT 372-404). This is the heady promise of

Geschichtlichkeit. ${ }^{39}$ As one might expect, it is the injunction to think of a historicity beyond the assumptions of presence (as the principal form of consciousness, the guiding relation to objects in the world and the measure of time) that prompts Derrida to emphasize his own terminology, notably difference, text, trace and repetition. 
Thanks to the 1964-1965 lectures, we can now see these terms as part of Derrida's engagement with the problem of history.

As we have seen, one of the most original aspects of Being and Time is that it begins with metaphysics, with the inauthentic as a necessity: the authentic first is not first (브 165-662). For Derrida, this is indicative of an "originary difference" in the ontic-ontological difference that cannot be reduced to a "simple and initial or final

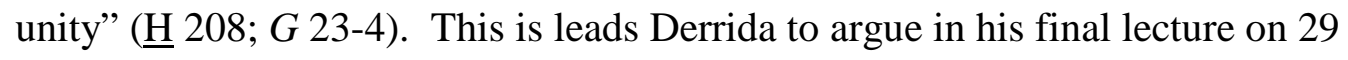
March 1965 that there must be “an irreducible multiplicity of historicities” (브 208). This is possible because Heidegger may speak at some length about the historicity of Dasein but has comparatively little to say about “authentic historicity” (BT 376, 38586). Derrida takes this as an affirmation that there is no "historicity in the proper sense” in Being and Time (ㅂ 164).

When Heidegger argues that the historicity of Dasein must precede "the history of Being," the proper sense of the authentic historicity is also - to use a phrase that we

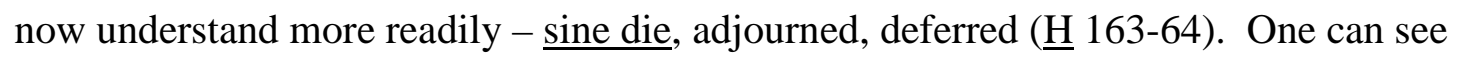
this as differance in the making. A deconstructive history cannot begin with the unique and assured origin of an authentic historicity, no matter what claims it makes to an exclusive and radical alterity. This is the level of critique that is lacking in the Marxist treatment of history.

A good example of the implications of thinking of history from a more radical notion of difference is Derrida's analysis of not beginning with the assumption of proximity. Derrida explains that in relation to Being, the there or Da of Da-sein is neither near nor far (표 87). As a movement that cannot be described as either an initial proximity or distancing, the Da of Dasein resists a simple spatial or anthropological designation ( $\underline{\mathrm{H}}$ 87). Derrida links this oscillation to a historicity and 
difference that makes the ontico-ontological difference possible and exceeds it. The "pre-ontological" announces a difference as "the unity of the near and the far" that cannot contained by a metaphysical concept of contradiction ( $\underline{\mathrm{H}}$ 90). For Derrida, "the contradictions are historicity: that is, the impossibility of a pure point of departure in the absolute proximity of the ontic or the ontological” ( $\underline{\mathrm{H}} 90)$.

This definition of historicity as no pure point of departure in the absolute proximity of a difference may seem a rather formal philosophical gesture. What makes Derrida’s engagement with the problem of history in the 1964-1965 lectures so compelling is how he goes on to associate this historicity with text, trace and, most significantly, repetition. Derrida makes the striking case in the fourth lecture for describing Da-sein (he retains the hyphen) as a text, by which he means "a synthetic multiplicity that holds to itself, retaining itself [se retenant elle-même],” which precedes the metaphysical soul-body, logos-text opposition (배 83). This dynamic retention registers the necessary relation to memory and the "gathering of past meaning” (보 83).

Derrida then turns to the relation between text and the trace. The trace registers text and can be treated as a necessary retention of the start of any spoken utterance as it reaches its end ( $\underline{\mathrm{H}}$ 83). While this gestures to the well-known treatment of speech and writing in general in Of Grammatology, it highlights problems that Derrida first gestures to in "Violence and Metaphysics." As Derrida notes in the sixth lecture, Levinas argued that the trace "withdraws from phenomenality and presence" and

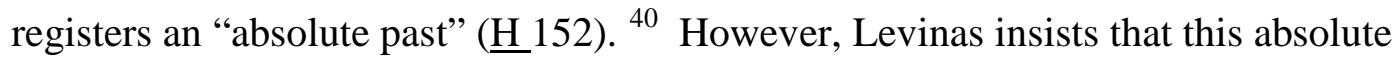
past is "non-history" because the other as infinitely other exceeds the history of the same ( $\underline{\mathrm{H}}$ 152). This leaves Derrida with the problem of the trace as an a-historical absolute past and the evocation of a non-historicity in the name of a radical alterity. 
Derrida will reaffirm in Of Grammatology that the trace must be understood as an absolute past to avoid being taken as a modification of the present ( $\underline{G}$ 66). But he will also add that the "strange movement of the trace" defers and differs from the proper sense of the absolute past ( $\underline{G}$ 66). He returns to this problem in 1968 and argues that differance has "its 'history" " and the trace of the absolute past can be no more ahistorical than historicist. ${ }^{41}$

One of the great contributions of the 1964-1965 lectures to Derrida studies is that it foregrounds the importance of Heidegger's treatment of repetition (Wiederholung) as a problem of history. In his final lecture, Derrida goes so far as to claim that repetition is "doubtless the only concept that is truly original and proper to a thematic

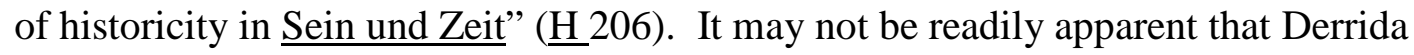
resolves the problem of the relation between the trace and history in $\underline{\mathrm{Of}}$ Grammatology. Thanks to the lectures, we can now see that one of the possible reasons for this is that Derrida treats Heidegger's notion of repetition as an autotradition or the registering of a historical past that is determined neither by its relation to objects or to the subject.

According to Derrida, in Being and Time repetition operates as a means of destroying the history of ontology because it avoids the classical metaphysical gesture

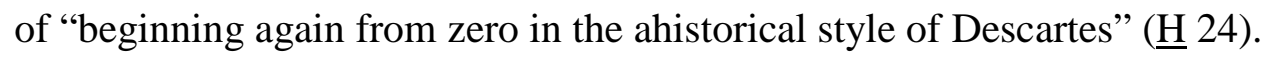
Repetition can therefore be seen as “deepening the enigma of temporality and historicity” (브 206). Derrida had already noted in 1962 how Husserl used repetition to secure transhistorical objective idealities such as geometry. ${ }^{42}$ In the lectures, he states clearly that in Husserlian phenomenology "the form of historicity is not historical" and therefore "the condition of historicity is a certain ahistoricity of historicity, a certain intemporality of time” (프 140). This should reinforce that 
Derrida is aware of the impasse of relying on an ahistorical framework to establish a radical historicity.

In contrast, Heidegger's hermeneutical phenomenology treats repetition as a facet of temporality rather than the means of trans-temporal ideality. As Gerhard Richter observes, for Heidegger Wiederholung does “not refer to a renewed processing of some sameness or self-sameness, but rather points to a thinking-retrieving experience of an as-yet undepleted sense of possibility.” 43 Before singling out repetition, Derrida had accorded a similar status to Heidegger's treatment of the concept of “inheritance and tradition or transmission” (ㅂ 176). ${ }^{44}$ Derrida suggests that the relation between repetition, heritage and tradition in Being and Time indicates the possibility of a historical transmission that does not rely on the ahistorical vantage points of Hegelian self-consciousness or Husserlian consciousness (프 200-1).

For Derrida, the critical point is that Heidegger's transmission through repetition is

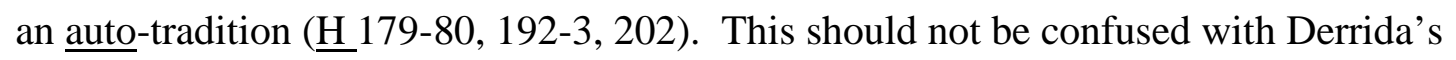
later account in Voice and Phenomenon (1967) of a pure auto-affection such as “hearing-oneself-speak” ( $\underline{\mathrm{VP}}$ 67-8; $\underline{\mathrm{G}}$ 98). As Derrida explains in the lectures, in

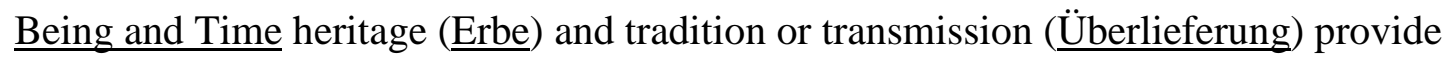
a structure for what Heidegger calls “handing down to oneself” (Sichüberlieferung) (BT 383). This handing-down to oneself can be described as "the self-tradition of an auto-transmission” (브 176). However, this should not be taken as a self-constituted tradition as one would find in Husserl's transcendental phenomenology. ${ }^{45}$ This handing to oneself is constituted by an auto-transmission, which arises from Heidegger's radical treatment of temporality.

In Being and Time the profound “enigma” of the past is partly resolved by temporality being described as "an ecstatical unity” in which time "temporalizes itself 
as a future which makes itself present in the process of having been” (BT 350, 365, 381). Time should no longer be seen as a linear and spatial succession of past, present and future mirroring what is behind, here and in front. As Heidegger observes, "the future is not later than having been, and having been is not earlier than the present” ( $\underline{\mathrm{BT}}$ 350). For Derrida, the auto-transmission that constitutes handingdown to oneself is an "originary historical synthesis" of the ecstatical unities of temporality ( $\underline{\mathrm{H}}$ 176). Heidegger’s auto-tradition registers the compelling link between temporality and historicity without founding this relation on the consciousness or constituting powers of the subject or a determining empirical context.

For Derrida, the challenge set by Heidegger is to think of a historicity that

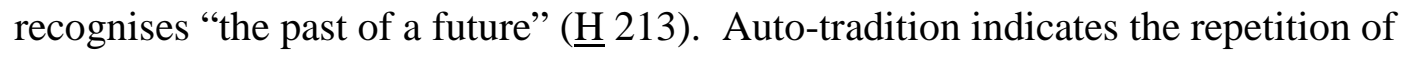
the past that opens the possibility of the future of the past: the past is not only behind us; it is also coming towards us. ${ }^{46}$ One can see this in the 1964-1965 lectures in Derrida’s interest in the links between à-venir and Geschehen, between what is to come and what happens (브 95-7, 140, 173). As Derrida explains in a 1989 interview, without a "simple origin," repetition or "the iterability of the trace" describes the immediacy of both a necessary unity and an unavoidable alteration. ${ }^{47}$ As "the condition of historicity,” repetition at once adheres to and exceeds “the unity of a context." 48

The 1964-1965 lectures show us that Heideggerian historicity played a significant role in the formation of Derrida's notions of difference and repetition in the years immediately preceding Of Grammatology. At the very least, this should prompt a reassessment of the account of history and historicity in Of Grammatology. However, the complexity and difficulty of this legacy for Derrida is apparent in a few concise pages from the interviews in Positions (1972). The problem of history for Derrida is 
still situated in this period in the political context of French Marxism and Althusser's treatment of history.

Derrida argues in Positions that the assertion of pluralist and heterogeneous histories - a position he associates with Althusser - inevitably raises "the question of the historicity of history." 49 This question leads to the problem of the essence of history, which traditionally culminates in an ontological grounding of historicity. This metaphysical impasse can be avoided if one asks "the question of the history of essence” ( $\underline{P}$ 59). This in turn can lead to the Heideggerian question of "the history of the meaning of Being” ( $\underline{\mathrm{P}} 59)$. However, Derrida implies that this sequence for addressing the problem of historicity - going from essence to the history of essence to the meaning of Being - also demonstrates “the risk of metaphysical reappropriation”

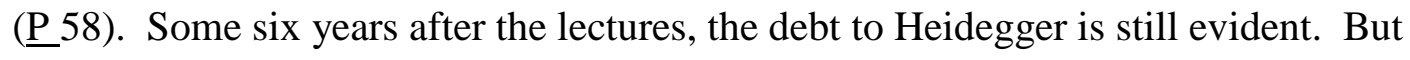
Derrida makes it clear that Heidegger's innovative link between temporality and historicity must be rethought from the vantage point of repetition and differance. For Derrida, it is the question of "a history that also implies a new logic of repetition and the trace, for it is difficult to see how there could be history without it” ( $\underline{\mathrm{P}} 57)$. This "new logic" should explain the enigma of the past, the possibility of the future of the past and a historicity that is not determined by the classical subject-object relation.

\section{THE EPOCHS OF HISTORICITY}

In Essential History (2005), Joshua Kates notes that Derrida still relies on Husserlian frameworks at various strategic moments in Of Grammatology, even if he challenges the grounds and aims of phenomenology ( $\underline{G}$ 60-7). ${ }^{50}$ As Derrida himself remarked in 1999, he has “always remained faithful” to the phenomenological 
reduction, Husserl's method for suspending the "natural attitude” to the subject, objects and the world. ${ }^{51}$ However, one can see how the 1964-1965 lectures alter our understanding of Derrida treatment of history leading up to Of Grammatology as Kates struggles to give an account of what he sees as an explicit move away from Husserl and towards Heidegger in this period (EH 179, 191, 197). Kates's conclusion that Derrida “defends” history in "Violence and Metaphysics” in 1964 and “abandons” it in Of Grammatology in 1967 is overstated but understandable (트 200, 209-10).

A striking example of Derrida's increased caution around concepts of history after the Heidegger lectures can be seen in his revisions for the 1967 publication of “Violence and Metaphysics.” In his 1964 essay he offers a provisional alternative to Levinas’s a-historical ethics in Totality and Infinity (1961) (VM 133-34). ${ }^{52}$ A philosopher might find him or herself “within history," Derrida observes, but only when history is taken as "the history of the departures from totality” (VM 117). There is then both finitude and a history that registers "the excess over the totality without which no totality would appear as such” (VM 117). In contrast to Levinas’s opposition of totality and infinity, this allows us to think of a history that is not infinite - which is the limitation of any phenomenological history - and which can still be greater than any finite totality.

This elegant argument can be taken as an instance of Derrida outmanoeuvring Levinas but it hardly constitutes a philosophy of history. This is in fact exactly what Derrida does not want to formulate. He is sufficiently concerned that there may be a misunderstanding about this that he adds three sentences - and two of these in italics - at the end of the 1967 version of his essay. ${ }^{53}$ Having taken Levinas's pejorative notion of "economy" as antithetical to the infinitely other, Derrida uses it to offer a 
limited but practical ethics. Rather than fall prey to the extreme alternatives of an absolute violence or an absolute peace (that can only be secured through an absolute violence), Derrida proposes an “economy of violence” ( $\underline{\mathrm{VM}}$ 117). By recognising an originary violence, one cannot avoid violence in relation to the other but one can at least resist "the worst violence” ( $\underline{\mathrm{VM}} 117)$. One must recognise that there are irreducible but variable degrees of violence. This is the "vigilance” taken by a “philosophy which takes history, that is, finitude, seriously” (VM 117; G 68). However, by 1967 Derrida wants it to be understood that "the economy of which we are speaking does not any longer accommodate the concept of history such as it has always functioned" (VM 148). This is not an abandonment of history - or the simple affirmation of finitude - but rather an indication that history has become a pressing and still unresolved problem for Derrida by 1967.

This becomes apparent when we turn to Of Grammatology. We can now see that there is one direct reference to the 1964-1965 lectures at the start of the second chapter, "Linguistics and Grammatology.” Derrida offers a succinct summary of the treatment of history in the Heidegger lectures and reaffirms what he sees as Heidegger's refusal to associate a deficient mode of historicity with non-historicity. What is interesting about this passage is that the more obvious debts to and differences from Heidegger have been added for the 1967 revisions to the 1965 article "Of Grammatology." 54 Derrida writes: "Historicity itself is tied to the possibility of writing; to the possibility of writing in general, beyond those particular forms of writing in the name of which we have long spoken of peoples without writing and without history. [Added in 1967] Before being the object of a history - of an historical science - writing opens the field of history - of historical becoming. And

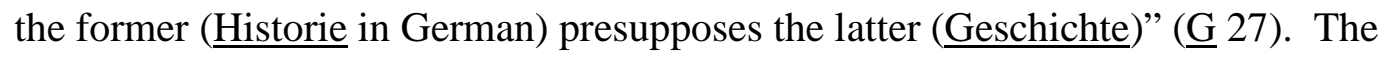


difference from the lectures is that Derrida now explicitly argues that "historicity

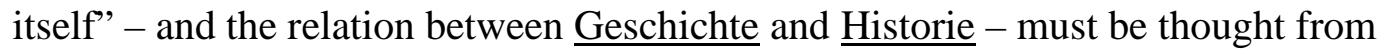
writing in general or differance. At the end of the 1964-1965 lectures, he already appears to mark the limits of Heideggerian history, observing that it is a historicity that can only be thought as a history of Being (프 224).

This implicit critique of Heidegger’s framework for history after Being and Time helps to answer why Derrida all but stops talking about Geschichtlichkeit after 1965. In Of Grammatology he argues "the concept of history itself” is found "within a logocentric epoch" ( $\underline{G}$ 5). But he also recognizes a "new mutation in the history of writing, in the history of writing” (G 8$)$. He refers to the limitations of the science of history and to the history of metaphysics, but offers no extended discussion of historicity (G 9, 13, 20, 23). Indeed, there are hardly any references to historicity in Of Grammatology. ${ }^{55}$ It is also remarkable that for a collection of such important papers and essays from 1967-1972, there are only three references to historicity in Margins of Philosophy (1972). ${ }^{56}$

This reticence tells us that Derrida does not simply take up Heidegger's terms or their definitions and apply them to his own thought. It also suggests that by 1967 Heidegger's historicity can now also be criticised from what amounts to a new "method" for reading the history of philosophy. ${ }^{57}$ As is well known, Derrida opens Of Grammatology with an unequivocal statement about the limits of history. He calls for a "reading [that] should escape, at least in its axis, from the classical categories of history: of the history of ideas, certainly, and the history of literature, but perhaps above all from the history of philosophy” ( $\underline{G}$ lxxxix). ${ }^{58}$ This is not an outright rejection of the history of philosophy; it is rather the declaration of a new way of treating the history of philosophy that avoids the common terminus of historicism and 
a-historicism - both of which, Derrida argues in the Heidegger lectures, assume that there is a subject "in history” (배 166). ${ }^{59}$

However, this does suggest that part of Derrida's problem with history in this period is the relation between historicity and the history of philosophy. In his muchcelebrated paper "Structure, Sign and Play in the Discourse of the Human Sciences" (1966), Derrida proposes that it is possible to "de-constitute" the "founding concepts of the entire history of philosophy” without falling back into a-historicism. ${ }^{60}$ One can begin this process, he argues, by interpreting the constant reappearance of the “non-center" in the history of philosophy "otherwise than as the loss of the center." 61 This proposes a different engagement with the history of philosophy not an abandonment of this history.

Appropriately, Derrida’s 1968 essay on Heidegger "Ousia and Grammē" articulates in more detail this different way of reading the history of philosophy. ${ }^{62}$ Derrida argues that Aristotle's account of time does not simply give us "time on the basis of ousia as parousia” and therefore the seamless metaphysics of "vulgar" time found, according to Heidegger in Being and Time, in both Aristotle and Hegel (ㅁ 61). Derrida's critique of Heidegger's summation of metaphysical time implies that the history of metaphysics can be treated as a deferral of and differing from the proper sense of this history: one does not need to read the history of metaphysics in a metaphysical manner. In this case, there is a discernable "play of submission and

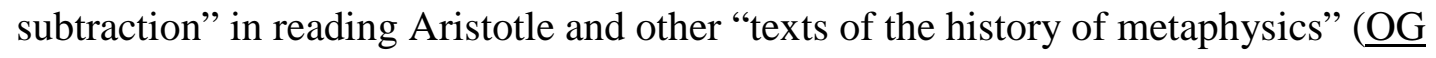
62). As Derrida later notes in Positions, avoiding "the metaphysical concept of history” requires treating the "closure” of metaphysics not as "a circle surrounding a homogenous field, a field homogenous with itself on its inside, whose outside then would be homogenous also” ( $\underline{\mathrm{P}} 57)$. 
It is from this vantage point that we can better understand Derrida's sharpened critique of Heidegger after the 1964-1965 lectures as a critique of Geschichtlichkeit when it is taken as the absolute or pure other of history. Significantly, while the lectures had emphasised that Heidegger recognises the derived as a necessity, in “Ousia and Grammē” Derrida criticises the metaphysical opposition of the originary and the derived in Heidegger's thought ( $\underline{\mathrm{H}}$ 166; $\underline{\mathrm{OG}}$ 63). This suggests that by 1968 Derrida was already questioning how far Heidegger actually avoids the metaphysical opposition between historicity and non-historicity. By the time of Of Spirit: Heidegger and the Question (1987), Derrida places Heidegger's historicity firmly within the problem of a "privileged relationship" to the question itself and to the German language in particular. ${ }^{63}$ It is the privilege in Heidegger's thought of the relation to being and a spirit-like gathering and directing of "what is sent” and “destined” (Geschick) that allows humans "to be and to have a history.” 64

Derrida's work on Heidgger in the late 1960s and 1970s suggests a general reassessment of the relation between an innovative historicity and a philosophically conservative, politically regressive ordering and directing of the history of Being ( $\underline{E}$ 108-9, 112). The Geschichtlichkeit of Dasein in Being and Time is one of the casualties of Heidegger's subsequent concentration on the history of Being and "the epochality of Being” (으 64). In contrast, in the 1964-1965 lectures Derrida implied that Heidegger has managed to claim an innovative notion of the epoch that is neither tied to history (as Wilhelm Dilthey) or independent of history (as Husserl) (프 12932). Historicity would then not be "enclosed in one epoch" (브 133).

Heidegger is able to offer this new understanding of the epoch because he reformulates Husserl’s notion of the phenomenological reduction or épokhē as a suspension of the natural attitude. As Derrida suggests in the lectures, Heidegger 
treats the epoch as an épokhē: the epoch of being accounts for both a "period and a suspension" in which being "brackets itself in a historical movement” (프 145). However, Heidegger also insists that the history of philosophy in its entirety is "the limited history of one epoch of being” (ㅍ 144). Derrida emphasizes this in the 19641965 lectures and one can already see that this monumentalization of the history of philosophy contradicts Derrida careful distinction at the start of Of Grammatology between the claims for a homogenous end and the permeable closure of metaphysics ( $\underline{G}$ 4). Derrida’s extended critique of Heidegger's epochs of being can be taken as an affirmation of an on-going engagement with a variegated history of philosophy.

When Derrida notes in 1968 that the word history still connotes "the final repression of difference” he most likely has in mind Hegel's history of spirit, which culminates in the end of history as absolute knowledge (ㅁ 11). But as we have seen, Derrida is always aware of the proximity of Heidegger and Hegel. He will also argue in 1968 that the history of Being itself - and its determined epochs of being and presence - is only an epoch of differance (ㅁ 22-3). Because the Heideggerian epoch has soldered together the historical and the history of Being, Derrida also suggests that the term epoch needs to be rethought as "the play of the trace” (ㅁ 22). As he argues in his 1980 paper “Envoi,” one can contrast the philosophical and historical limitations of treating the history of Being as "the unity of a destination" to a “multiplicity of renvois [referrals],” of "many different traces referring back to other traces” (E 121, 127). ${ }^{65}$ As Derrida had argued in the 1964-1965 lectures, these referrals back to other traces is the possibility of history and of a historicity that is confined neither to the classical subject nor to the Heideggerian epochs of being ( $\underline{E}$ 127-28). 
HISTORY OF PHILOSOPHY AND PHILOSOPHY OF HISTORY

Despite the confident assertion made on Derrida's behalf some thirty years ago that “différance names the historicity of history," the dynamic and elusive variations of differance as “(at once) spacing (and) temporization” could be taken as the basis for an ambitious philosophy of history that is comparable with Hegel's Aufhebung, Husserl's epokhē, and Heidegger's history of Being (D 13). ${ }^{66}$ Derrida's earliest substantial work, his 1954 dissertation on Husserl and the problem of genesis, opens with the question of the relation between "history of philosophy and philosophy of history.” 67 How far does this relation remain a problem for Derrida after the 19641965 Heidegger lectures?

In his first comments on the general limitations of history in Of Grammatology Derrida does not include the philosophy of history ( $\underline{G}$ lxxxix). The only reference to the philosophy of history in Of Grammatology appears directly after the summary of the 1964-1965 lectures. It is cited as part of series of questions, of problems that still remain to be addressed. As in the previous paragraph, there are notable additions to the 1967 revisions. Derrida writes: “The science of writing should therefore look for its object at the roots of scientificity. The history of writing should turn back toward the origin of historicity. A science of the possibility of science? A science of science which would no longer have the form of logic but that of grammatics? A history of the possibility of history [added in 1967] which would no longer be archaeology, a

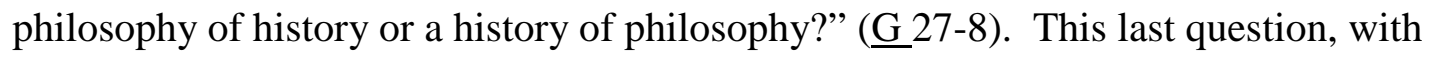
its significant additions in 1967, highlights the difficulty of thinking of the old pairing of the history of philosophy and the philosophy of history from the perspective of "the history of differance, [of] history as differance." 68 
As we have seen, for Derrida differance has "its 'history' " and therefore cannot be taken as an ahistorical origin for a certain kind of historicity (ㅁ 7). There is a history of differance: its distinctive histories are apparent in Derrida's use of different terms to register its dynamics and shifting contexts in the history of philosophy, as well as in a range of literary and political works. But when Derrida speaks of history as differance to account for the possibility of history, can this also be understood as a pervasive philosophy of history?

Unlike Paul Ricoeur, Derrida did not seek out a hermeneutical philosophy that could embrace a "confrontation with the history of the historians." ${ }^{69}$ Derrida also did not follow Heidegger, who makes rigorous distinctions in Being and Time between

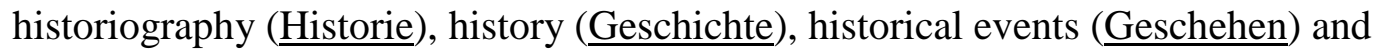
historicity (Geschichtlichkeit) as the basis for a "concrete working out” (konkretere Ausarbeitung) of the question of the meaning of being (BT 375, 378, 282). Derrida does not use history as a "concrete working out" of "the becoming-space of time and

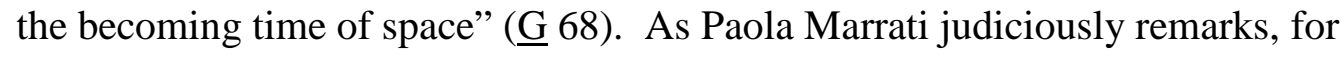
Derrida "if there is a history, it cannot be gathered and thought in terms of the Heideggerian concept of Geschichte, in terms of the opposition between Geschichte and Historie." ${ }^{70}$ In work from the 1960s to the 1990s, Derrida challenged the

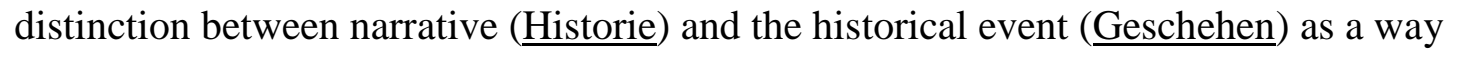
of questioning Heidegger's assured sequence of historical possibility in which Geschichte must always precede $\underline{\text { Historie. }}{ }^{71}$

One can of course question the determinations of "philosophy" and "history" as the necessary conditioning for a philosophy of history. Derrida himself does this at the end of Of Grammatology ( $\underline{G}$ 286). Much as Derrida treats Artaud “at the limit,” reading him at once as still inside and beyond metaphysics, one can describe Derrida 
himself at the limit in relation to the history of philosophy and the philosophy of history. Derrida speaks in a 1981 interview of attempting to find "a nonphilosophical site, from which to question philosophy” so that it can "appear to itself as other than itself.” ${ }^{72}$ That Derrida's work can today be taken as part of the history of philosophy perhaps shows that philosophy can expand both its horizons and its many others.

Nonetheless, in Derrida's thought there is the need for some kind of suspension or epokhē of history, and especially of its historicist and relativist determinations, even if this placing in parenthesis is itself historical ( $\underline{\mathrm{G}} 7)$. Marrati describes this gesture as the condition for a "historicity in general" that remains neither simply in history (as an empirical historicism), nor outside of history (as a transcendent ahistorical possibility). ${ }^{73}$ This is a very persuasive conclusion; but it can also still be taken as the conditions for a philosophy of history that comprehends the shared possibility and complicity of a-historicism and historicism.

It is perhaps only when Derrida's seminars have been published that we can begin to understand the philosophical and political conditions for a possible deconstructive historicity. As Derrida observed in 1989, he has sought not only to critique historicism but also to find a historicity "beyond, against and without Husserl or Heidegger” ( $\underline{\mathrm{PF}}$ 157). ${ }^{74}$ Derrida notably makes use of the term historicity in his later work. In Rogues (2002), for example, he speaks of an "essential historicity of democracy” and this can be taken as a very appropriate political reorientation of Heidegger's historicity. ${ }^{75}$ The most significant legacy for Derrida of the problem of history as raised by Heidegger may be the "historicity of the political.” 76

These lectures, delivered by the thirty-four year old Derrida at the start of his remarkable career, affirm that Derrida takes from Heidegger what he sees as the 
innovation of beginning with the question of history by not insisting on a determined non-historicity. For Derrida, such an approach to history will facilitate the common critique of enthnocentrism and logocentrism ( $\underline{\mathrm{H}} 310) .{ }^{77}$ Fifty years later, we now know that the ethics and philosophical innovations of this treatment of history were dramatically short-lived in Heidegger's thought. Its true legacy is found in $\underline{\mathrm{Of}}$ Grammatology. 
NOTES

${ }^{1}$ Jacques Derrida, Heidegger: The Question of Being and History, ed. Thomas Dutoit with the assistance of Marguerite Derrida, trans. Geoffrey Bennington (Chicago: Univ. of Chicago Press, 2016) (hereafter cited as $\underline{\mathrm{H}})$.

${ }^{2}$ Jacques Derrida, Of Grammatology, trans. Gayatri Chakravorty Spivak (Baltimore: Johns Hopkins Univ. Press, 1976), lxxxix (hereafter cited as $\underline{G}$ ); Jacques Derrida, “ ‘This Strange Institution Called Literature’: An Interview with Jacques Derrida,” in Acts of Literature, ed. Derek Attridge, trans. Geoffrey Bennington and Rachel Bowlby (London: Routledge, 1992), 54.

${ }^{3}$ Jacques Derrida, “Privilege: Justificatory Title and Introductory Remarks,” in Who’s Afraid of Philosophy: Right to Philosophy I, trans. Jan Plug (Stanford: Stanford Univ. Press, 2002), 10.

${ }^{4}$ Edward Baring, "Ne me raconte plus d'histoires: Derrida and the Problem of the History of Philosophy,” History and Theory 53 (May 2014): 176.

5 Jacques Derrida, The Problem of Genesis in Husserl's Philosophy, trans. Marian Hobson (Chicago: Univ. of Chicago Press, 2003); Jacques Derrida, Edmund Husserl’s Origin of Geometry: An Introduction, trans. and intro. John P. Leavey, Jr. (Lincoln: Univ. of Nebraska Press, 1989); Jacques Derrida, “ “Genesis and Structure” and Phenomenology,” in Writing and Difference, ed. Alan Bass (Chicago: University of Chicago Press, 1978), 154-68.

${ }^{6}$ Louis Althusser, Étienne Balibar, et al., Reading Capital: The Complete Edition, trans. Ben Brewster and David Fernbach (London: Verso, 2016), 268-95. See also, Louis Althusser, For Marx, trans. Ben Brewster (London: Verso, 2005). 
${ }^{7}$ Jacques Derrida, "Politics and Friendship," in Negotiations: Interventions and Interviews 1971-2001, ed. Elizabeth Rottenberg, trans. Robert Harvey (Stanford: Stanford Univ. Press, 2002), 151 (hereafter cited as $\underline{\text { PF). }}$

${ }^{8}$ Benoît Peeters, Derrida: A Biography, trans. Andrew Brown (Cambridge: Polity, 2013); Edward Baring, The Young Derrida and French Philosophy, 1945-1968 (Cambridge: Cambridge Univ. Press, 2011).

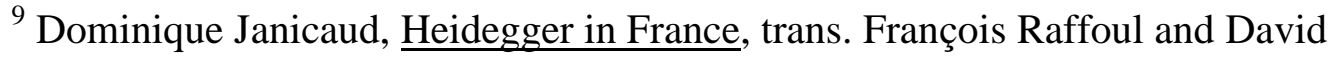
Pettigrew (Bloomington: Indiana Univ. Press, 2015).

${ }^{10}$ Jacques Derrida, “Ousia and Grammē: Note on a Note from Being and Time,” in Margins of Philosophy, trans. Alan Bass (Chicago: Univ. of Chicago Press, 1982), 62 n. 37 (hereafter cited as $\underline{\mathrm{OG}}$ ). See also Dominique Janicaud, “Jacques Derrida: Interviews of July 1 and November 22, 1999,” in Heidegger in France, trans. François Raffoul and David Pettigrew (Bloomington: Indiana Univ. Press, 2015), 337-63.

${ }^{11}$ Martin Heidegger, Überlegungen: Schwarze Hefte 1931-1941, ed. Peter Trawny, 3 vols (Frankfurt am Main: Vittorio Klostermann, 2014). These have been partially translated as Ponderings II-VI: Black Notebooks 1931-1938, trans. Richard Rojcewicz (Bloomington: Indiana Univ. Press, 2016). See also, Reading Heidegger’s Black Notebooks 1931-1941, ed. Inigo Farin and Jeff Malpas (Cambridge: MIT Press, 2016).

12 Jean-Luc Nancy, Banalité de Heidegger (Paris: Galilée, 2015), 41. My translation.

${ }^{13}$ Banalité de Heidegger, 41, 47. My translation. See Heidegger, Überlegungen:

Schwarze Hefte 1931-1941, II: 99, III: 17, 77, 82, 121.

${ }^{14}$ Peter Trawny, Heidegger and the Myth of a Jewish World Conspiracy, trans. Andrew J. Mitchell (Chicago: Univ. of Chicago Press, 2015); David Nirenberg, AntiJudaism: The History of a Way of Thinking (London: Head of Zeus, 2013). 
${ }^{15}$ Emmanuel Levinas, “Toward the Other,” in Nine Talmudic Readings, trans. and intro. Anette Aronowicz (Bloomington: Indiana Univ. Press, 1994), 25.

${ }^{16}$ Jacques Derrida, Hans-Georg Gadamer and Philipe Lacoue-Labarthe, Heidegger, Philosophy and Politics: The Heidelberg Conference, ed. Mireille Calle-Gruber, fore. Jean-Luc Nancy, trans. Jeff Fort (New York: Fordham Univ. Press, 2016), 35.

${ }^{17}$ Banalité de Heidegger, 14.

${ }^{18}$ See Jacques Derrida, “Envoi,” in Psyche: Inventions of the Other, Volume 1, ed. Peggy Kamuf and Elizabeth Rottenberg, trans. Peter and Mary Ann Caws (Stanford: Stanford Univ. Press, 2007), 94-128 (hereafter cited as E); “Envois,” in The Post Card: From Socrates to Freud and Beyond, trans. Alan Bass (Chicago: Univ. of Chicago Press, 1987), 1-256.

${ }^{19}$ Jacques Derrida, “Geschlecht I: Sexual Difference, Ontological Difference,” in Psyche: Inventions of the Other, Volume II, ed. Peggy Kamuf and Elizabeth Rottenberg, trans. Ruben Bevezdivin and Elizabeth Rottenberg (Stanford: Stanford Univ. Press, 2008), 7-26; Jacques Derrida, “Heidegger’s Hand (Geschlecht II),” in Psyche: Inventions of the Other, Volume II, ed. Peggy Kamuf and Elizabeth Rottenberg, trans. John P. Leavey Jr. and Elizabeth Rottenberg (Stanford: Stanford Univ. Press, 2008), 27-62; Jacques Derrida, Of Spirit: Heidegger and the Question, trans. Geoffrey Bennington and Rachel Bowlby (Chicago: Univ. of Chicago Press, 1989); Jacques Derrida, “Heidegger’s Ear: Philopolemology (Geschlecht IV),” in Reading Heidegger: Commemorations, ed. John Sallis, trans. John Leavey Jr. (Bloomington: Indiana Univ. Press, 1992), 163-218; Jacques Derrida, Aporias: Dying - Awaiting (One Another at) the 'Limits of Truth'," trans. Thomas Dutoit (Stanford: Stanford Univ. Press, 1993); Jacques Derrida, The Animal That Therefore I Am, ed. Marie-Louise Mallet, trans. David Wills (New York: Fordham Univ. Press, 2008), 
141-60; Jacques Derrida, The Beast and the Sovereign, Volume 1, trans. Geoffrey Bennington, ed. Michel Lisse, Marie-Louise Mallet, and Ginette Michaud (Chicago: Univ. of Chicago Press, 2009), 305-49; The Beast and the Sovereign, Volume II, trans. Geoffrey Bennington, ed. Michel Lisse, Marie-Louise Mallet, and Ginette Michaud (Chicago: Univ. of Chicago Press, 2011).

${ }^{20}$ Martin Heidegger, Sein und Zeit (Frankfurt am Main: Vittorio Klostermann, 1977);

Being and Time, trans. John Macquarrie and Edward Robinson (Oxford: Blackwell, 1962), 390 (citing page numbers in the margins). Hereafter cited as BT.

${ }^{21}$ Derrida, Edmund Husserl's Origin of Geometry,114. Translation modified.

${ }^{22}$ See Derrida, Of Spirit: Heidegger and the Question. See also, Jacques Derrida, “Heidegger, the Philosophers’ Hell,” in Points ... : Interviews, 1974-1994, ed. Elisabeth Weber, trans. John P. Leavey Jr. (Stanford: Stanford Univ. Press, 1995), 181-90; Trawny, Heidegger and the Myth of a Jewish World Conspiracy, 16.

${ }^{23}$ Derrida, “Geschlecht I: Sexual Difference, Ontological Difference,” 11. See also Rodolphe Gasché, The Tain of the Mirror: Derrida and the Philosophy of Reflection (Cambridge: Harvard Univ. Press, 1986), 136-42.

${ }^{24}$ Jacques Derrida, Glas, trans. John P. Leavey Jr. and Richard Rand (Lincoln: Univ. of Nebraska Press, 1986), 200a.

${ }^{25}$ Derrida suggests that Heidegger would have approved of Hegel's insistence that the German language is especially suited to philosophy since it can conjure such dynamic terms as Aufhebung ( $\underline{\mathrm{H}}$ 101). As Françoise Dastur has noted, it is also most likely Hegel who coined the neologism Geschichtlichkeit that Dilthey and Count Yorck handed on to Heidegger, Françoise Dastur, 'Heidegger: Historie et historicité - le débat avec Dilthey et l'influence de Yorck von Wartenberg', in Heidegger en dialogue 1912-1930: Rencontres, affinités et confrontations, ed. Servanne Jollivet et 
Claude Romano (Paris: Vrin, 2009), 11-32: 23-4. See for example, Georg Wilhelm

Friedrich Hegel, Vorlesungen über die Geschichte der Philosophie I (Surkamp:

Frankfurt am Main, 1971), 175; Lectures on the History of Greek Philosophy: Greek

Philosophy to Plato, trans. E. S. Haldane, intro. Frederick C. Beiser (Lincoln: Univ. of Nebraska Press, 1995), 151.

${ }^{26}$ Jacques Derrida, Heidegger: la question de l'Être et l'Histoire: Cours de l'ENS-

Ulm 1964-1965, ed. Thomas Dutoit avec le concours de Marguerite Derrida (Paris:

Galilee, 2013), 57.

${ }^{27}$ See also Jacques Derrida, “If There Is Cause to Translate II: Descartes’ Romances, or The Economy of Words,” in Eyes of the University: Right to Philosophy 2, trans.

Rebecca Coma (Stanford: Stanford Univ. Press, 2004), 20-42.

${ }^{28}$ Derrida, Of Spirit, 58-72; Derrida, The Animal That Therefore I Am, 141-60;

Derrida, The Beast and the Sovereign, Volume 1, 305-49; The Beast and the

$\underline{\text { Sovereign, Volume II. See also Martin Heidegger, The Fundamental Concepts of }}$ Metaphysics: World, Finitude, Solitude, trans. William McNeill and Nicholas Walker (Bloomington: Indian Univ. Press, 1995); G. W. F. Hegel, Philosophy of Nature, Part Two of the Encyclopaedia of the Philosophical Sciences (1830), trans. A. V. Miller, fore. J. N. Findlay (Oxford: Clarendon Press, 1970).

${ }^{29}$ See also Janicaud, Heidegger in France, 339.

${ }^{30}$ Derrida, Heidegger: la question de l'Être et l'Histoire, 288.

${ }^{31}$ See Jacques Derrida, The Politics of Friendship, trans. George Collins (London: Verson, 1997). He returns to this passage in “Heidegger’s Ear,” 176.

${ }^{32}$ Martin Heidegger, 'Letter on "Humanism” ', in Basic Writings, ed. and intro.

David Farrell Krell, trans. Frank A. Capuzzi, $2^{\text {nd }}$ edn (New York Harper Collins, 1993), 236. 
33 See Jacques Derrida, “White Mythology: Metaphor in the Text of Philosophy,” in Margins of Philosophy, trans. Alan Bass (Chicago: Univ. of Chicago Press, 1982), 207-71; Jacques Derrida, “The Retrait of Metaphor,” in Psyche: Inventions of the Other, Volume 1, ed. Peggy Kamuf and Elizabeth Rottenberg, trans. Peggy Kamuf (Stanford: Stanford Univ. Press, 2007), 48-80.

${ }^{34}$ Jacques Derrida, "Violence and Metaphysics: An Essay on the Thought of Emmanuel Levinas," in Writing and Difference, trans. Alan Bass (Chicago: Univ. of Chicago Press, 1978), 138 (hereafter cited as VM). See also Michael Naas, "Violence and Historicity: Derrida’s Early Readings of Heidegger,” Research in Phenomenology 45 (2015): 191-213.

${ }^{35}$ Derrida gives an extended analysis of proximity and Heidegger in Jacques Derrida, “The Ends of Man,” in Margins of Philosophy, trans. Alan Bass (Chicago: Univ. of Chicago Press, 1982), 123-34.

${ }^{36}$ Jorge Luis Borges, “The Fearful Sphere of Pascal,” in Labyrinths, ed. Donald A. Yates and James E. Irby, pref. André Maurois (London: Penguin, 1970), 227.

${ }^{37}$ Jacques Derrida, “La parole soufflée,” in Writing and Difference, trans. Alan Bass (Chicago: Univ. of Chicago Press, 1978), 194 (hereafter cited as $\underline{\text { PS) }}$.

${ }^{38}$ Translation modified.

${ }^{39}$ Marc Goldschmit, ‘Le Mouvement métaphorique de l’histoire sous la peau métaphysique du langage - notes sur un cours inédit de Jacques Derrida (Novembre 1964 - Mars 1965), Revue métaphysique et de morale 71, no. 3 (2011): 377.

${ }^{40}$ Emmanuel Levinas, “The Trace of the Other,” in Deconstruction in Context: Literature and Philosophy, ed. Mark C. Taylor, trans. A. Lingus (Chicago: Univ. of Chicago Press, 1986), 345-59. 
${ }^{41}$ Jacques Derrida, “Différance,” in Margins of Philosophy (Chicago: Univ. of Chicago Press, 1982), 7 (hereafter cited as $\underline{\mathrm{D}})$.

${ }^{42}$ Derrida, Edmund Husserl's Origin of Geometry: An Introduction, 34, 46-8, 72-4.

See also Jacques Derrida, Voice and Phenomenon: Introduction to the Problem of the

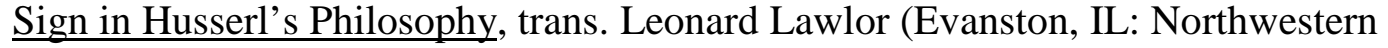
Univ. Press, 2011), 44-6 (hereafter cited as VP).

${ }^{43}$ Gerhard Richter, “The Debt of Inheritance Revisited: Heidegger’s Mortgage, Derrida’s Appraisal,” Oxford Literary Review 37, no. 1 (2015): 74.

${ }^{44}$ On Derrida’s concept of heritage see, “Discussion between Jacques Derrida, Philippe Lacoue-Labarthe and Jean-Luc Nancy,” in For Strasbourg: Conversations of Friendship and Philosophy, ed. and trans. Pascale-Anne Brault and Michael Naas (New York: Fordham Univ. Press, 2014), 17-30

${ }^{45}$ See Paul Ricoeur, "Husserl and the Sense of History,” in Husserl: An Analysis of his Phenomenology, trans. Edward G. Ballard and Lester E. Embree, fore. David Carr (Evanston: Northwestern Univ. Press, 2007), 143-74; Dermot Moran, Husserl’s Crisis of the European Sciences and Transcendental Phenomenology: An Introduction (Cambridge: Cambridge Univ. Press, 2012).

${ }^{46}$ See Jacques Derrida, Parages, ed. John P. Leavey Jr. (Stanford: Stanford Univ. Press, 2011), 11-102; Jacques Derrida, Specters of Marx: The State of the Debt, the Work of Mourning, and the New International, intro. Bernd Magnus and Stephen Cullenberg, trans. Peggy Kamuf (London: Routledge, 1994), 25, 31-2; Jacques Derrida, Rogues: Two Essays on Reason, trans. Pascale-Anne Brault and Michael Naas (Stanford: Stanford Univ. Press, 2005).

${ }^{47}$ Derrida, “ ‘This Strange Institution Called Literature’,” 64.

${ }^{48}$ Derrida, “ 'This Strange Institution Called Literature’,” 64-5. 
${ }^{49}$ Jacques Derrida, Positions, trans. and notes Alan Bass (Chicago: Univ. of Chicago Press, 1981), 58 (hereafter cited as $\underline{\mathrm{P}}$ ).

${ }^{50}$ Joshua Kates, Essential History: Jacques Derrida and the Development of Deconstruction (Evanston: Northwestern Univ. Press, 2005), 160-6, 168-79 (hereafter cited as $\underline{\underline{E H}})$.

${ }^{51}$ Janicaud, “Jacques Derrida,” 341. See also Jacques Derrida, “Et Cetera... (and so on, und so weiter, and so forth, et ainsi de suite, und so überall, etc.),” in

Deconstructions: A User’s Guide, trans. Geoffrey Bennington, ed. Nicholas Royle (Basingstoke: Palgrave, 2000), 282-305; Edmund Husserl, Ideas Pertaining to a $\underline{\text { Phenomenological Philosophy: First Book - General Introduction to a Pure }}$ Phenomenology, trans. F. Kersten (The Hague: Martinus Nijhoff, 1983), 51-62, 10912.

52 Emmanuel Levinas, Totality and Infinity: An Essay on Exteriority, trans. Alphonso Lingus (Pittsburgh: Duquesne Univ. Press, 1969).

53 Jacques Derrida, “Violence et métaphysique: Essai sur la pensée d’Emmanuel Levinas,” Revue de Métaphysique et de Morale 69, no. 4 (Octobre-Décembre 1964), 467. See also Baring, The Young Derrida and French Philosophy, 187-88.

54 Jacques Derrida, “De la grammatologie (I),” Critique 21, no. 233 (Décembre 1965): 1031.

${ }^{55}$ Of Grammatology, 27, 33, 121, 128, 178, 246, 337 n. 19. While there are more than thirty references in Writing and Difference to historicity, only two of these appear in works written after 1965, Jacques Derrida, Writing and Difference, trans. Alan Bass (Chicago: Univ. of Chicago Press, 1978), 269, 291.

${ }^{56}$ Jacques Derrida, Margins of Philosophy, trans. Alan Bass (Chicago: Univ. of Chicago Press, 1982), 64 (on Heidegger), 122-23 (on Husserl). 
${ }^{57}$ At the start of Of Grammatology Derrida rejects the idea of his work as "a new method" (lxxxix).

58 Translation modified.

${ }^{59}$ See also Baring, “Ne me raconte plus d'histoires," 178-80.

60 Jacques Derrida, “Structure, Sign and Play in Discourses of the Human Sciences,” in Writing and Difference, trans. Alan Bass (Chicago: Univ. of Chicago Press, 1978), 284 (translation modified). See Geoffrey Bennington Jacques Derrida (Chicago: Univ. of Chicago Press, 1993), 284-91.

${ }^{61}$ Derrida, “Structure, Sign and Play,” 292 (translation modified).

${ }^{62}$ See Herman Rapaport, Heidegger and Derrida: Reflections on Time and Language (Lincoln: Univ. of Nebraska Press, 1989), 69-79.

${ }^{63}$ Derrida, Of Spirit, 76.

${ }^{64}$ Of Spirit, 76.

${ }^{65}$ On the translation of renvois as referral, see Geoffrey Bennington, "Embarrassing Ourselves,” Los Angeles Review of Books, 20 March 2016

(https://lareviewofbooks.org/article/embarrassing-ourselves).

66 Translation modified. Introduction to Post-Structuralism and the Question of History, ed. and intro. Derek Attridge, Geoff Bennington and Robert Young (Cambridge: Cambridge Univ. Press, 1987), 9. See also Dominik LaCapra, Rethinking Intellectual History: Texts, Contexts, Language (New York: Cornell Univ. Press, 1983), 29, 44-45, 140.

${ }^{67}$ Derrida, The Problem of Genesis, xvii.

${ }^{68}$ Jacques Derrida, “Freud and the Scene of Writing,” in Writing and Difference, trans. Alan Bass (Chicago: Univ. of Chicago Press, 1978), 197.

${ }^{69}$ Ricoeur, “Husserl and the Sense of History,” 169. 
${ }^{70}$ Paola Marrati, Genesis and Trace: Derrida Reading Husserl and Heidegger, trans. Simon Sparks (Stanford: Stanford Univ. Press, 2005), 106.

${ }^{71}$ Jacques Derrida, Given Time: 1 Counterfeit Money, trans. Peggy Kamuf (Chicago: Univ. of Chicago Press, 1992), 121-22; Jacques Derrida, "History of the Lie:

Prolegomena,” in Without Alibi, ed. and trans. Peggy Kamuf (Stanford: Stanford Univ. Press, 2002), 38. See also Baring, “Ne me raconte plus d'histoires” 180-81.

72 Jacques Derrida, “Deconstruction and the Other,” in Dialogues with Contemporary Thinkers: The Phenomenological Heritage, ed. Richard Kearney (Manchester: Manchester Univ. Press, 1984), 108.

${ }^{73}$ Marrati, Genesis and Trace, 108. See also Bennington, Jacques Derrida, 267-84.

${ }^{74}$ See also Derrida, Specters of Marx, 74-5.

${ }^{75}$ Derrida, Rogues, 25. See also 72, 86-7, 91.

${ }^{76}$ Jacques Derrida and Elisabeth Roudinesco, For What Tomorrow ... Dialogue, trans. Jeff Fort (Stanford: Stanford Univ. Press, 2004), 127. See also Derrida’s comments on the political heritage of Heidegger in Heidegger, Philosophy and Politics: The Heidelberg Conference, 19, 34-5.

${ }^{77}$ In "Structure, Sign and Play,” Derrida argues that the "ethnologist accepts into his discourse the premises of ethnocentrism at the very moment when he denounces them” (282). This argument is developed in Of Grammatology (39, 76-7, 79-80, 83-4, 90-2, 10-21, 211, 221-2). I would like to thank Deborah Thebault and Geoffery Bennington. 